UDK 547.992.2

\author{
*E.T. Yermoldina, Zh.K. Kairbekov, \\ Institute of New Chemical Technologies and materials Al-Farabi Kazakh National University Kazakhstan, Almaty \\ "E-mail: ermoldina@mail.ru
}

\title{
Palladium - potassium humate coated by Polymetallic catalysts for the process of hydrogenation of nitrocompounds
}

\begin{abstract}
Results of studies of humic substances in the quality of natural polymeric modifier for the coated palladium catalysts are presented in the paper. Synthesis of new catalysts based on palladium - potassium humate fixed on various inorganic carriers and their catalytic properties have been studied. The catalysts of $0,8 \%$ Pd - Potassium's Humat(1\%)/B-94 and $0,8 \% \mathrm{Pd} /$ Shungite $1 \% \mathrm{KOH}$ are optimal.

Key words: humic acids, synthesis, catalysts, natural polymers, Shungite, hydrogenation.

Ж.Қ. Қайырбеков, Э.Т. Ермолдина

Нитроқосылыстарды тотықсыздандыру процесіндегі палладий-калий гуматы негізіндегі қондырылған полимерметалл катализаторлары
\end{abstract}

Берілген мақалада қондырылған палладий катализаторына гумин препаратының табиғи полимер-модификкатор ретінде қолданылуы және ол катализаторлардың каталитикалық қасиеті нитроқосылыстарды гидрлеу процесінде зерттелді. Палладий - калий гуматы негізінде әртүрлі бейорганикалық тасымалдағышқа қондырылған жаңа катализаторлар синтезделді. 0,8% Рd-калий гуматы (1\%) / Боксит-094 және 0,8\% Pd / Шунгит.1% КОН катализаторлары ең оптималды және анағұрлым активті болып табылды.

Түйін сөздер: гумин қышқылдары, синтез, катализаторлар, табиғи полимерлер, гидрлеу.

Ж.К. Каирбеков, Э.Т. Ермолдина

Нанесенные полимерметаллические катализаторы палладий-гумат калия

в процессе гидрирования нитросоединений

В работе представлены результаты исследования по разработке полимерметаллических катализаторов на основе природного полимера-гумат калия и палладия. Каталитические свойства разработанных катализаторов были исследованы в реакциях гидрирования нитросоединений. В качестве носителей и полимера использовали природные материалы. Оптимальными катализаторами являются 0,8 \% Pd-калий гуматы (1\%) / Боксит-094 и 0,8 \% $\mathrm{Pd} /$ Шунгит 1\% КОН.

Ключевые слова: гуминовые кислоты, синтез, катализаторы, природные полимеры, гидрирование.

\section{Introduction}

The development of new type of catalysts, combining the advantages of inorganic and organic ion exchange properties has become a topical problem recently. Such catalysts may be obtained by fixation of the surface of inorganic substances by organic substances, containing ionogenic functional groups. The utilization is possible of natural mineral source, which possesses not only adsorption and ion exchange properties, but is also cheap, and abundant. For instance, it may be highly efficient catalysts based on fixed complexes of humic acids with metals of VIII group with inorganic matrix of natural origin. In works [1-3] the high efficiency of palladium catalysts is noted. Thus, the polymers [4], containing fragments of trans $-\mathrm{M}-\left(\mathrm{CH}_{2}-\mathrm{CH}_{2}-\right.$ $\left.\mathrm{C}_{6} \mathrm{H}_{4} \mathrm{~N}\right)_{2} \mathrm{Cl}$, where $\mathrm{M}$ may be palladium or platinum were obtained. Thus, the authors have found the selectivity of nitrocompounds and almost complete reduction to corresponding amines, while polymer complexes of palladium possessed high activity, compared to platinum complexes.

Related to this the humic acids (HA) and compounds on their basis have become the objects of studies. This is related to the fact, that these substances possess numerous valuable properties, 
the main of which are - abundance and ecological security. Humic acids can enter various chemical transformations and are very rich initial material for obtaining natural-synthetic polymers of numerous forms of purpose and properties - qualitatively new preparates with properties of higher level [5].

According to modern conceptions humic acids (HA) - this group of amorphous dark coloured aromatic polymers of ox carbonic acids, united by general principle of structure, but different in composition in wide range depending on the character of initial charcoal. These high-molecular compounds with the nucleous of condensed carbon contain various functional groups, primarily, oxygen containing (phenolic, hinoid, carboxylic, methoxylic, ketonic, ether).

Aromatic nuclei contain from 2 to 6 condensed benzene rings [6-7]. Humic acids are related to polyelectrolyte [8]. Their acidic properties are due to the presence in the structure of HA of carboxylic and phenolic groups, the content of which changes depending on the source, from which they are extracted. According to literature data [8], the range of content of carboxylic groups in various preparations of HA may vary within the interval of $1.5-5.7 \mathrm{mg} * \mathrm{eq} / \mathrm{g}$, and in phenolic hydroxyls 2.1-5.7 mg*eq/g. The development of methods of preparation of monodisperse homogeneously fixed on carriers catalysts with nanosizes of particles of active phase gave new impetus to utilization of soluble polymers with various functional groups for stabilization of nanoparticles on carriers. Besides, the utilization of polymermetallic complexes causes the increase of interest of researchers due to the development of combinatorial chemistry and development of new processes, including multiple use of catalysts.

Topicality of studies of polymermetals in the catalysis is supported by the fact, that the leading foreign companies study such systems in numerous industrial processes of organic synthesis. The main achievement of latest years in this direction is the development of industrial technologies based on the multifunctional polymermetallic catalysts and their introduction to the industry.

\section{Materials and methods}

In the work catalysts were prepared by impregnation method. A bauxite-094 (B-094) hinge plate $(3 г)$ brought on $150 \mathrm{ml}$ of the distilled water, then when hashing added humate of potassium solution $(0,7-2,0$ masses. $\%$ in relation to mass of the carrier) At the same time added water solution of chloride of a palladium (1,0 мacc.\%). The received catalysts mixed within 3 hours, and then washed out, filtered and dried at temperature $383 \mathrm{~K}$ within two hours.

Samples were investigated in the analytical center of Xingjian university by means of an electronic microscope by a TEM method of remarks with an extracts with application of microdiffractions (of Hitachi, Japan. Instrument Type: H-600, electronic microscope of SEM Instrument Type: LEO1430VP ).

Catalytic properties were tested in thermostats "duck" with electrodes for measurement of potential of the catalyst. Hashing carried out by acceleration of "duck" with speed of 650-700 in a minute. It allows to carry out process for lack of diffusive braking.

Potential of the catalyst measured by means of voltmeter. Reliability of kinetic results proves to be true accuracy of individual measurement and reproducibility of experimental data.

\section{Results and Discussion}

As potassium humate may form polymermetallic complex with palladium [8-10] we studied the possibility of utilization of humic preparations in the quality of natural polymer-modifier for coated palladium catalysts, and new catalysts are synthesized based on palladium-potassium humate, fixed on various inorganic carriers and their catalytic properties are studied (table 1). In the quality of nitrocompounds potassium ortho-nitro phenolate (PONP) and paranitrodiethylaniline (PNDA) were studied.

According to table 1 during reduction of PONP the high rates of reaction are observed on the catalysts $\mathrm{Pd} / \mathrm{B}-094, \mathrm{Pd} /$ Shungite (Sht) and Pd/NiO. The shift of potential of catalyst during reduction of PONP is 240-322 mV (table 1), which serves as evindence of adsorption of PONP and absence of hydrogen on the surface of the catalyst. The rate of reaction is limited by activation of PONP and strengthening of bond of hydrogen with the surface of catalyst leads to more favourable relation of concentration of reacting components on the surface of catalyst, in the result of which the rate increases of reduction of organic nitrocompound. 
During reduction of PONP on catalysts covering the oxides $\left(\mathrm{NiO}, \mathrm{SiO}_{2}, \mathrm{Al}_{2} \mathrm{O}_{3}\right)$, the activity increases with the increase of specific surface of carrier. And on the catalysts on the natural minerals, the activity depends on the acid-base properties of carrier. Thus, with the increase of values of isoelectric point of carrier (from acidic to amphoteric) the activity of catalysts increases, and then on the transition to isoelectric point from amphoteric to basic the activity decreases.

During reduction of PNDA on the catalysts on the surface of oxides $\left(\mathrm{NiO}, \mathrm{SiO}_{2}, \mathrm{Al}_{2} \mathrm{O}_{3}\right)$, the activity increases with the increase of specific surface of the carrier. And on the catalysts on the surface of natural minerals with the low specific surface, activity also depends on acid-base properties of the carrier. Thus, with the increase of values of isoelectric point of carrier (from acidic to amphoteric) the activity of catalysts increases, and then on transition to isoelectric point from amphoteric to basic the activity decreases. High rates of reaction of reduction of PNDA in ethanol are also observed on the catalysts $\mathrm{Pd} / \mathrm{Sht}, \mathrm{Pd} / \mathrm{NiO}, \mathrm{Pd} / \mathrm{B}-094$. The shift of potential of catalyst during reduction of PNDA constitutes 100-141 mV (table 1), which serves as evidence of adsorption of hydrogen and PNDA. The rate of reaction is limited by activation of both hydrogen and PNDA.

On palladium catalysts covering $\mathrm{SiO}_{2}, \mathrm{Al}_{2} \mathrm{O}_{3}$ and charcoal of Oy-Karagay mine field the reduction occurs with lower rate, compared to catalysts of $\mathrm{Pd} / \mathrm{Sht}, \mathrm{Pd} / \mathrm{NiO}, \mathrm{Pd} / \mathrm{B}-094$ and $\mathrm{Pd} / \mathrm{Ct}$. The studied catalysts may be placed in the following row according to activity: $\mathrm{Pd} / \mathrm{Sht}>\mathrm{Pd} / \mathrm{NiO}>\mathrm{Pd} / \mathrm{B}-094$ $>\mathrm{Pd} / \mathrm{SiO}_{2}>\mathrm{Pd} / \mathrm{Al}_{2} \mathrm{O}_{3}>\mathrm{Pd} / \mathrm{C}_{\text {oy-karagay }}$

Table 1 - The rate of reduction of PONP in $0,1 \mathrm{~N} \mathrm{KOH} \mathrm{under} 313 \mathrm{~K}\left(\mathrm{P}_{\mathrm{atw}}, \mathrm{q}_{\mathrm{cat}}=0,1 \mathrm{~g}, \mathrm{~m}_{\mathrm{ONP}}=0,21 \mathrm{~g}, \mathrm{~V}_{\mathrm{H} 2}=100 \mathrm{~cm}^{3}\right)$ and PNDA in ethanol at $333 \mathrm{~K}\left(\mathrm{P}_{\text {atm }}, \mathrm{q}_{\text {catalyst }}=0,1 \Gamma, \mathrm{m}_{\mathrm{PONP}}=0,29 \mathrm{~g}, \mathrm{~V}_{\mathrm{H} 2}=100 \mathrm{~cm}^{3}\right)$ on the catalysts $0,8 \% \mathrm{Pd} /$ carrier

\begin{tabular}{|c|c|c|c|c|c|c|c|c|}
\hline \multirow[t]{2}{*}{ Catalyst } & \multirow[t]{2}{*}{$\begin{array}{l}\text { Isoel. Point of } \\
\text { carrier }\end{array}$} & \multirow[t]{2}{*}{$\begin{array}{c}\text { Specific } \\
\text { surface of } \\
\text { the carrier, } \\
\mathrm{m}^{2} / \mathrm{g}\end{array}$} & \multicolumn{2}{|c|}{$\begin{array}{l}\text { Rate of reduction of PONP } \\
\text { (solvent- } 0,1 \mathrm{n} \mathrm{KOH}) \\
\mathrm{cm}^{3} / \mathrm{min}\end{array}$} & \multirow[t]{2}{*}{$\begin{array}{c}\text { Shift. Of } \\
\text { potential of the } \\
\text { catalytst, } \\
\mathrm{D} \varphi, \mathrm{mV}\end{array}$} & \multicolumn{2}{|c|}{$\begin{array}{l}\text { Rate of reduction of } \\
\text { PNDA } \\
\text { (solvent-ethanol), } \\
\mathrm{cm}^{3} / \mathrm{min}\end{array}$} & \multirow[t]{2}{*}{$\begin{array}{c}\text { Shift of } \\
\text { potential of } \\
\text { the catalyst, } \\
\mathrm{D} \varphi, \mathrm{mV}\end{array}$} \\
\hline & & & $\mathrm{W}_{\text {initial }}$ & $\mathrm{W}_{\text {average }}$ & & $\mathrm{W}_{\text {initial }}$ & $\mathrm{W}_{\text {average }}$ & \\
\hline $\mathrm{Pd} / \mathrm{SiO}_{2}$ & $\begin{array}{l}1,0-2,0 \\
\text { Acidic }\end{array}$ & 156,0 & 6,2 & 5,8 & 300 & 18,4 & 18,4 & 120 \\
\hline $\mathrm{Pd} / \mathrm{Al}_{2} \mathrm{O}_{3}$ & $\begin{array}{r}7,0-9,0 \\
\text { amphot. }\end{array}$ & 88,0 & 4,8 & 4,3 & 240 & 13,6 & 12,8 & 110 \\
\hline $\mathrm{Pd} / \mathrm{NiO}$ & $\begin{array}{c}10,5-11,0 \\
\text { basic. }\end{array}$ & 200,0 & 11,3 & 8,0 & 260 & 34,4 & 30,0 & 110 \\
\hline $\mathrm{Pd} / \mathrm{Sht}$ & $\begin{array}{r}5,0-6,5 \\
\text { amphot. }\end{array}$ & 5,0 & 11,7 & 10,3 & 309 & 35,6 & 32,6 & 100 \\
\hline $\begin{array}{l}\mathrm{Pd} / \mathrm{Sht} \\
\text { proc. } 1 \% \\
\mathrm{KOH}\end{array}$ & $\begin{array}{l}7,0-8,0 \\
\text { amphot }\end{array}$ & 7,7 & 23,8 & 18,3 & 270 & 42,6 & 42,2 & 100 \\
\hline $\mathrm{Pd} / \mathrm{C}_{\text {ой-караг }}$ & $\begin{array}{l}9,0-9,8 \\
\text { basic. }\end{array}$ & 11,8 & 5,0 & 3,6 & 250 & 1,6 & 1,4 & 100 \\
\hline Pd/B-094 & $\begin{array}{r}5,0-7,0 \\
\text { amphot. }\end{array}$ & 38,3 & 16,0 & 15,2 & 289 & 21,6 & 21,6 & 139 \\
\hline
\end{tabular}

With the aim of improvement of functional characteristics (or activity, stability) of catalysts, it is important to develop the method of preparation, under which the main mass of active metal would be located on external attainable surface of carrier. Realization of such method became possible with the use of properties of palladium chloride(II) to form polymeric complexes under variation of $\mathrm{pH}$ of aqueous solution.

In the quality of natural polymer for preparation of polymermetallic catalysts the potassium humate (PHum) was chosen. The content of PHum in the catalyst varied from 0.7 to 2.0 mass $\%$.

On figure 1 the electronmicroscopic image 
is shown of the sample of potassium humate (1). From the figure it can be seen the nature of PHum. Analysis of microphotograph has shown, that the initial powder of PHum exhibits practically defectless particles of polyhedric shape.

The study of activity of catalysts was carried out in the reactions of reduction of PONP in the media of $0.1 \mathrm{~N} \mathrm{KOH}$ under $313 \mathrm{~K}$ and PNDA in ethanol under $333 \mathrm{~K}$.
On reduction of PONP according to activity the catalysts may be place in the following order: PdPHum /B-094 > Pd-PHum/Sht proc. $1 \% \mathrm{KOH}>\mathrm{Pd}-$ PHum $/$ Sht $>$ Pd- PHum $/ \mathrm{SiO}_{2}>$ Pd- PHum $/ \mathrm{Al}_{2} \mathrm{O}_{3}$. Processing of carrier (shungit) by base in the catalyst Pd- PHum /Sht weakly increases its activity (about $5 \%$ ). The shift of potential of catalysts constitutes 290-320 mV, which supports adsorption on the surface of catalyst of PONP (table 2).

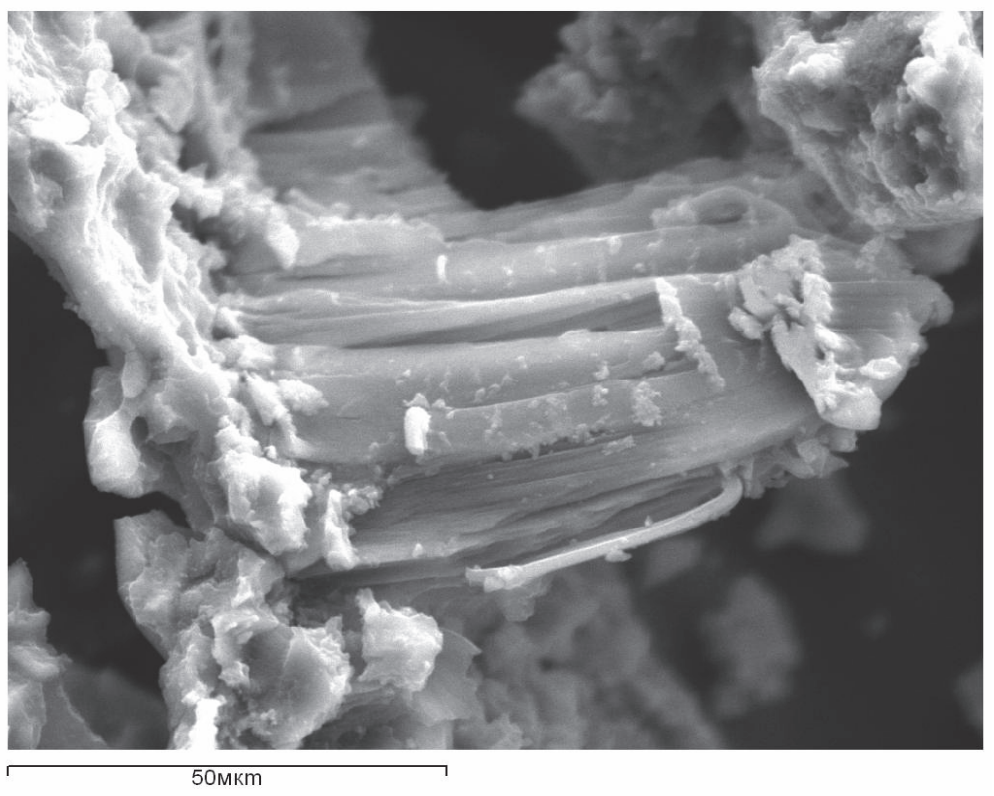

Figure 1 - Microphotograph of the sample: potassium humate

Catalysts, obtained by fixation of such polymermetallic complex on natural minerals, are more active (table 2), than catalysts, obtained by fixation of only palladium on the same carriers (table 1). Optimal concentration of active phase (palladium) in catalysts constitutes 0.8 mass.\%, and potassium humate -1.0 mass.\%. Processing of shungite (Sht) (carrier) by base increases activity of Pd- PHum /Sht catalyst, but more higher values of the rate of reaction under hydrogenation of nitrocompounds is observed on the $\mathrm{Pd} / \mathrm{Sht}$ catalyst, proc. $1 \% \mathrm{KOH}$ (table 2).

Table 2 - Rate of reduction of ONP on the catalysts of $0.8 \%$ Pd- PHum $(1 \%) /$ carrier in $0.1 \mathrm{~N} \mathrm{KOH}$ at $313 \mathrm{~K}\left(\mathrm{P}_{\text {atm }}, \mathrm{q}_{\text {cat }}\right.$ $\left.=0,1 \mathrm{~g}, \mathrm{~m}_{\mathrm{PONP}}=0,21 \mathrm{~g}, \mathrm{~V}_{\mathrm{H} 2}=100 \mathrm{~cm}^{3}\right)$ and PNDA in ethanol at $333 \mathrm{~K}\left(\mathrm{P}_{\mathrm{atm}}, \mathrm{q}_{\text {catalyst }}=0,1 \mathrm{~g}, \mathrm{~m}_{\mathrm{PONP}}=0,29 \mathrm{~g}, \mathrm{~V}_{\mathrm{H} 2}=100 \mathrm{~cm}^{3}\right)$

\begin{tabular}{|c|c|c|c|c|c|c|}
\hline \multirow{2}{*}{ Catalyst } & \multicolumn{2}{|c|}{$\begin{array}{l}\text { Rate of reduction of PONP } \\
\qquad \mathrm{cm}^{3} / \mathrm{min}\end{array}$} & \multirow{2}{*}{$\begin{array}{l}\text { Shift of potential } \\
\text { of the catalyst, } \\
\text { D } \varphi, m V\end{array}$} & \multicolumn{2}{|c|}{$\begin{array}{l}\text { Rate of reduction of PNDA, } \\
\qquad \mathrm{cm}^{3} / \mathrm{min}\end{array}$} & \multirow{2}{*}{$\begin{array}{l}\text { Shift of potential of } \\
\text { the catalyst, } \\
\mathrm{D} \varphi, \mathrm{mV}\end{array}$} \\
\hline & $\mathrm{W}_{\text {initial }}$ & $\mathrm{W}_{\text {average }}$ & & $\mathrm{W}_{\text {initial }}$ & $\mathrm{W}_{\text {avarage }}$ & \\
\hline Pd- PHum $/ \mathrm{SiO}_{2}$ & 12,6 & 11,5 & 300 & 19,8 & 19,2 & 160 \\
\hline Pd- PHum /Sht & 17,7 & 17,3 & 300 & 38,0 & 38,0 & 160 \\
\hline $\begin{array}{c}\text { Pd- PHum } / \text { Sht, } \\
\text { proc. } 1 \% \mathrm{KOH}\end{array}$ & 18,5 & 18,5 & 310 & 19,9 & 19,9 & 230 \\
\hline Pd- PHum /B-094 & 25,2 & 25,2 & 320 & 33,3 & 33,3 & 160 \\
\hline
\end{tabular}


From the data of table 2 it can be said, that in ethanol the high rates of hydrogenation of PNDA are observed on the catalysts Pd-HumK/Sht and PdHumK/B-94. Here the value of the shift of potential is $120-230 \mathrm{mV}$, meaning the adsorption on the surface of the catalyst of both hydrogen and PNDA.

During reduction of PONP the catalysts may be placed in the following order according to activity: Pd-PHum/B-094 > Pd-PHum/Sht, proc.1\%KOH > $\mathrm{Pd}-\mathrm{PHum} / \mathrm{Sht}>>\mathrm{Pd}-\mathrm{PHum} / \mathrm{SiO}_{2}$.

Processing of carrier (shungit) by base in the catalyst Pd-PHum/Sht weakly (about 5\%) increases its activity. The shift of potential of catalyst constitutes $290-320 \mathrm{mV}$, which supports adsorption on the surface of the catalyst of PONP (table 2).

\section{Conclusion}

Hence, the conclusion may be made, that potassium humate is able to form polymetallic complex with palladium. PHum produces stabilizing effect in the process of preparation of the catalyst. Catalysts, obtained by fixation of this polymer metallic complex on inorganic oxides and natural minerals, are more active, than catalysts obtained by fixation of only palladium on the same carriers. Optimal concentration of active phase (palladium) in catalysts is $0.8 \%$ and potassium humate -1.0 mass $\%$. The activity of catalysts fixed on shungit is positively affected by processing of shungit (carrier). Such processing increases the activity of the catalyst $\mathrm{Pd} / \mathrm{Sht}$. More higher values of the rate of reaction during reduction of nitrocompounds are observed on the catalyst Pd-PHum/B-094.

Thus, based on the obtained results it can be stated, that from all developed and tested catalysts, the most active and optimal are catalysts $0,8 \% \mathrm{Pd}-$ PHum (1\%)/B-094 and 0,8\% Pd/Sht proc. $1 \% \mathrm{KOH}$.

\section{References}

1 Ufluand I.E., Sheinker V.N., Bulatov A.V., Pomgaelo A.D. Hydrogenation of unsaturated and nitrocompounds on polymer supported palladium chelates // Journal of Mol.Catal. - 1989. - № 44 - P. 25-26.

2 Ihenguan I., Quanying L., Yunhong S., Ma J. Catalytic hydrogenation on palladium catalyst on the cianethylcellyose // Journal of Mol.Catal. - 1990. - vol. 4, - № I. - P.60-68. [Iang Ienguan, Liu Quanying, Sun Yunong, Ma Jueming. Kataliticheskoe gidrirovanie nitrosoedineniy na palladievom katalizatore, nanesennom na tsianoetiltsellyulozu // Journal of Mol.Catal.. - 1990. - Vol.4, № I. - P.60$68]$.

3 Tereshko L.V., Klyuev M.V. Hydrogenation of aromatic nitrocompounds in the presence of Pd-containing polythreemethylolmelamine [Gidrirovanie aromaticheskikh v prisutsvii Pd-soderzhashchego politrimetilolmelamina] // Mater. Konf. Mol.uchenykh him. Fak MGU Moskva Materials of conference. - Moscow, 1998. - P. 31-34.

4 Saha Ch.R., Bhattacharya S. Reduction of nitroaromatics with poly (vinylpyridine) complexes of Pd 11 and Pt $11 / /$ Journal of Chem.Technol. and Biotechnol. - 1987. - Vol. 37, № 4. - P. 233-245.

5. Ojima I. Catalytic Asymmetric Synthesis // Materials of conference. - Moscow, 1993. - P. 334.

6 Dzhardimalieva G. I., Golubeva N.D., Pomogailo A.D. Polymer Supported Reactions in Organic Chemistry // Materials of $7^{\text {th }}$ Intern. Conf. on Polymer Supported Reactions. -Wroclaw, 1996. - P. 86.

7 Kasatochkin V.I., Larina I.K. Structure and properties of natural coals [Stroenie i svoistva prirodnykh uglei] // Materials of conference. - Moscow, 1975. - P.159.

8 Zharmagambetova A., Muchamedzhanova S., Becturov E. Hydrogenation catalysts based on palladium complexes with poly(vinylpyridine)s. // Journal of Reactive Polymers. - 1994. -Vol. 24. -P.17-20

9 Zharmagambetova A., Muchamedzhanova S., Dusembina B. Catalytic hydrogenation over platinum cvomplexes with poly(vinylpyridine)s. // Journal of Reactive polymers. - 1994. - Vol. 234. -P. 21-25.

10 Zharmagambetov A.K., Muchamedzhanova S.G., Bekturov E.A. Catalysts of hydrogenation based on Pd (II) complexes. // Journal of Appl. Chem. 1991. - Vol. 12. - P. 2547-2551. 